\title{
Stimulation with LH of progesterone production by rabbit corpora lutea in vitro*
}

\author{
S. Damle†, A. R. LaBarbera $\ddagger$ J. B. Miller§ and M. Hunzicker-Dunn $\dagger$ \\ Departments of $\uparrow$ Molecular Biology and $\ddagger$ Obstetrics and Gynecology, Northwestern University \\ Medical School, Chicago, IL 60611, and \$Department of Obstetrics and Gynecology, University of \\ Illinois College of Medicine at Chicago, Chicago, Illinois 60612, U.S.A.
}

\begin{abstract}
Summary. Quartered CL from 7-day pseudopregnant rabbits were incubated at $37^{\circ} \mathrm{C}$ for $0-180 \mathrm{~min}$ in the presence of BSA, LH or adrenaline in Krebs-Ringer-bicarbonate buffer. Total progesterone at each time point was quantified in homogenates of tissue plus incubation media and expressed relative to $\mathrm{CL}$ protein. Progesterone increased linearly with time during the first $30 \mathrm{~min}$ of incubation in the presence of BSA. LH and adrenaline markedly accelerated progesterone accumulations relative to the BSA control. At $10 \mathrm{~min}$, progesterone accumulation in the presence of $\mathrm{LH}$ and adrenaline were 2.4 and 5.9 times that in the absence of stimulators, respectively. Both hormones caused concentration-dependent increases in progesterone and the apparent $E D_{50}$ was $0.75 \mu \mathrm{g} / \mathrm{ml}$ for $\mathrm{LH}$ and adrenaline. The CL obtained from ovaries of 7-day pseudopregnant rabbits are therefore capable of an acute steroidogenic synthetic response to LH as well as adrenaline.
\end{abstract}

\section{Introduction}

Previous studies have clearly documented that while LH is absolutely required to initiate corpus luteum formation in all species, progesterone production by corpora lutea $(\mathrm{CL})$ and $\mathrm{CL}$ maintenance in rabbits requires oestrogen and not LH (Bill \& Keyes, 1983; Hunzicker-Dunn \& Miller, 1983). Oestradiol is therefore considered to be the principal luteotrophic hormone in rabbits because it is sufficient for maintenance of serum progesterone concentrations in hypophysectomized pseudopregnant and pregnant rabbits and withdrawal causes rapid luteal regression (Keyes \& Nalbandov, 1967; Rennie, 1968; Spies et al., 1968; Holt et al., 1975; Bender et al., 1978; Bill \& Keyes, 1983). The rabbit CL in fact appears to be a typical oestradiol target tissue, exhibiting specific, high-affinity and low-capacity oestrogen receptors (Yuh \& Keyes, 1979; Drake \& Cook, 1979; Miller \& Toft, 1983) which appear with the physiological dependence of CL function on oestrogen (Mills \& Osteen, 1977; Miller \& Keyes, 1978) and disappear with luteal demise (Miller \& Toft, 1983). However, an acute and strong steroidogenic response to oestradiol has not been demonstrated.

Steroidogenesis in virtually all other tissues is thought to be regulated by trophic hormones via surface membrane receptors and a cAMP-mediated process. Rabbit CL, like other steroidogenic tissues, also exhibit the initial responses for $\mathrm{LH}$ - and catecholamine-directed functions. These include LH and catecholamine surface receptors (Abramowitz et al., 1982; Miller et al., 1986), an adenylate cyclase responsive to both effectors (Hunzicker-Dunn \& Birnbaumer, 1976; HunzickerDunn, 1982) and type I and II forms of cAMP-dependent protein kinase (Hunzicker-Dunn \& Jungmann, 1978). Changes in these measures appear to correlate with luteal function. LH receptor

*Reprint requests to Dr M. Hunzicker-Dunn, Department of Molecular Biology, Northwestern University Medical School, 303 East Chicago Avenue, Chicago, IL 60611, U.S.A. 
concentrations and LH- and adrenaline-stimulated adenylate cyclase activities increase dramatically during CL formation and decrease markedly with luteal demise (Hunzicker-Dunn \& Birnbaumer, 1976; Hunzicker-Dunn, 1982; Miller et al., 1986). The appearance and disappearance of the type I form of cAMP-dependent protein kinase similarly correlate with luteinization and luteolysis (Hunzicker-Dunn \& Jungmann, 1978), and it is this type I form of cAMP-dependent protein kinase which is activated acutely after i.v. injection of hCG (Hunzicker-Dunn, 1981).

Since rabbit CL require oestrogen to sustain progesterone production yet also possess at least the initial response for LH- and catecholamine-directed functions, we questioned whether the rabbit $\mathrm{CL}$ was able to produce progesterone acutely in response to $\mathrm{LH}$ or adrenaline. Previous studies had not firmly established or rejected steroidogenic actions for LH or adrenaline in rabbit CL. In-vivo studies have been clouded by the robust steroidogenic response of rabbit interstitial tissue to LH (Yuh \& Keyes, 1981), making it impossible to distinguish a luteal response. Ectopic CL (transplanted to the kidney capsule of ovariectomized rabbits) gave an inconsistent acute progesterone response, as measured in peripheral serum, to the i.v. injection of hCG (50 i.u.), presumably due to the low amounts of transplanted luteal tissue present (J. B. Miller, unpublished observations). In-vitro studies by Dorrington \& Kilpatrick $(1966,1967)$ and Wilks et al. (1970) demonstrated only slight $(30-35 \%)$ increases in progesterone accumulation by rabbit CL slices incubated with LH for 3 or $2 \mathrm{~h}$, respectively.

The present studies were therefore designed to determine whether rabbit CL are able to produce progesterone in vitro in response to an acute stimulus by adrenaline or LH. A preliminary account of the findings has been published in abstract form (Damle et al., 1984).

\section{Materials and Methods}

Materials. LH (NIH-LH-S18) was obtained from the Pituitary Hormone Distribution Program, NIAMMD, Bethesda, MD. Adrenaline $\mathrm{HCl}$ was from Parke-Davis and Co., Detroit, $\mathrm{MI}$, bovine serum albumin (BSA, fraction $\mathrm{V}$, charcoal purified) from Sigma Chemical Co., St Louis, MO, $\left[1,2,6,7-{ }^{3} \mathrm{H}\right]$ progesterone (sp. act. $112 \mathrm{Ci} / \mathrm{mmol}$ ) from New England Nuclear, Boston, MA, scintillation fluid 3a70B from Research Products International, Mount Prospect, IL, gelatin from Difco Laboratories, Detroit, MI, Dextran T70 from Pharmacia Fine Chemicals, Piscataway, NJ, and petroleum ether (reagent grade) was from American Scientific, McGaw Park, IL. Charcoal (carbon, decolorizing Norit A) was purchased from Eastman Kodak Co., Rochester, NY, and was washed before use. All other biochemical reagents were obtained from Sigma Chemical Co.

Preparation and incubation of corpora lutea. New Zealand White rabbits $(3-3 \cdot 5 \mathrm{~kg})$ which had littered at least once were obtained from Lesser Rabbitry, Union Grove, WI. Animals were individually caged in a temperature-controlled room with $14 \mathrm{~h}$ of light each day. Purina rabbit chow and water were freely available. Pseudopregnancy was induced on Day 0 with an i.v. injection of 100 i.u. hCG (Ayerst Laboratories Inc, NY) dissolved in $0.9 \%(\mathrm{w} / \mathrm{v}) \mathrm{NaCl}$. The rabbits (30) were killed by cervical dislocation on Day 7 of pseudopregnancy. Ovaries were removed and CL were immediately dissected, quartered with razor blades, and placed into capped $20-\mathrm{ml}$ glass vials (1 CL equivalent per vial) containing $2.5 \mathrm{ml}$ Krebs-Ringer-bicarbonate buffer (KRB), prepared with half the recommended amount of $\mathrm{CaCl}_{2}$ and equilibrated with $95 \% \mathrm{O}_{2} / 5 \% \mathrm{CO}_{2}$ (Cohen, 1951). Incubations for each datum point in a single experiment were in duplicate and tissues for each duplicate incubation were obtained from different animals. Two rabbits were used for each experiment. BSA (diluted from $1 \mathrm{mg} / \mathrm{ml}$ stock), LH (NIH-LH-S18, diluted from $1 \mathrm{mg} / \mathrm{ml}$ stock prepared in $0.1 \mathrm{M}-\mathrm{NaCl}$ ) or adrenaline (diluted from $1 \mathrm{mg} / \mathrm{ml}$ isotonic $\mathrm{NaCl}$ stock) were diluted into $\mathrm{KRB}$ just before the addition of tissue. $\mathrm{CL}$ were incubated at $37^{\circ} \mathrm{C}$ for up to $180 \mathrm{~min}$ in a shaking water bath. For incubations longer than $1 \mathrm{~h}$, incubation vessels were re-gassed every hour. Incubations were terminated by rapidly freezing incubation vessels in an acetone-solid $\mathrm{CO}_{2}$ bath.

For studies with rat CL, 28-day-old female rats (Charles River, Boston, MA; $\mathrm{Crl}: \mathrm{CD}^{\mathrm{R}}(\mathrm{SD}) \mathrm{BR}$ Sprague-Dawley outbreds) were injected s.c. with 50 i.u. PMSG followed $54 \mathrm{~h}$ later with 50 i.u. hCG. Rats were killed 7 days after the hCG injection by cervical dislocation. Ovaries were sliced with a razor blade, and incubated as described above $(1 / 8$ equivalent ovary per vial).

Progesterone radioimmunoassay. The total progesterone concentration (tissue plus medium) was quantified by the radioimmunoassay described by Day \& Birnbaumer (1980). The antiserum (GDN No. 337, kindly provided by Dr G. D. Niswender, Colorado State University) was raised in sheep. Gibori et al. (1977) have reported that GDN No. 337 showed only minimal cross-reactivity to $20 \alpha$-hydroxypregn-4-en-3-one $(1 \cdot 7 \%)$ compared with progesterone $(100 \%)$. For progesterone determinations, the contents of each incubation vessel were thawed and homogenized with 15-20 strokes of a 5-ml Potter-Elvehjem tissue grinder (Kontes, Vineland, NJ). Progesterone was extracted from triplicate 
$10-\mu$ aliquants of homogenates with $8 \mathrm{ml}$ petroleum ether by shaking at room temperature for $30 \mathrm{~min}$ in an automatic shaker. Tritiated progesterone ( 3000 c.p.m.) was added to each tube before extraction to correct for procedural losses, which averaged about $30 \%$. The ether extracts were then evaporated to dryness and reconstituted with $0.5 \mathrm{ml}$ PBS-gel buffer $(0.15 \mathrm{M}-\mathrm{NaCl} 0.5 \mathrm{M}$-potassium phosphate buffer, $\mathrm{pH} 7.2,0.1 \%$ gelatin). Aliquants of samples $(0.1 \mathrm{ml})$ or standards were incubated $\left(4^{\circ} \mathrm{C}, 18 \mathrm{~h}\right)$ in triplicate with tritiated progesterone $(14000 \mathrm{c.p} . \mathrm{m}$.$) and antiserum (final dilution$ 1:3000) in a total volume of $0.3 \mathrm{ml}$. Unbound progesterone was separated from the antigen-antibody complex by dextran-coated charcoal (3.12\% charcoal, $0.62 \%$ dextran, T70) adsorption according to Hotchkiss et al. (1971). Antibody-bound $\left[{ }^{3} \mathrm{H}\right]$ progesterone was quantified by scintillation spectrometry. Assay sensitivity was $5-15 \mathrm{pg}$, the midpoint of the standard curve was $90-150 \mathrm{pg}$, and the interassay and intra-assay coefficients of variation were $<10 \%$. Results were calculated with the aid of a CDC Cyber 170 computer using the 4 parameter model logistic curve-fitting program of Rodbard (DeLean et al., 1978) and are expressed as units of total progesterone accumulated per $\mu \mathrm{g}$ luteal protein. Tissue content of progesterone at the start of the incubation was subtracted from values obtained at each incubation time.

Other methods. Protein was determined according to the technique of Lowry et al. (1951), using crystalline BSA as a standard in $40 \mu \mathrm{l}$ aliquants of homogenate. Data comparisons were performed using the Student's $t$ test.

\section{Results and Discussion}

Rabbit CL produced progesterone in vitro. In control (BSA) incubations total luteal progesterone increased in a linear manner, but only during the first $30 \mathrm{~min}$ of incubation (Fig. 1a). The addition of $\mathrm{LH}$ or adrenaline at $10 \mu \mathrm{g} / \mathrm{ml}$ clearly accelerated progesterone accumulation. At $10 \mathrm{~min}$, LHand adrenaline-stimulated progesterone accumulation exceeded control values by $2 \cdot 4$-fold

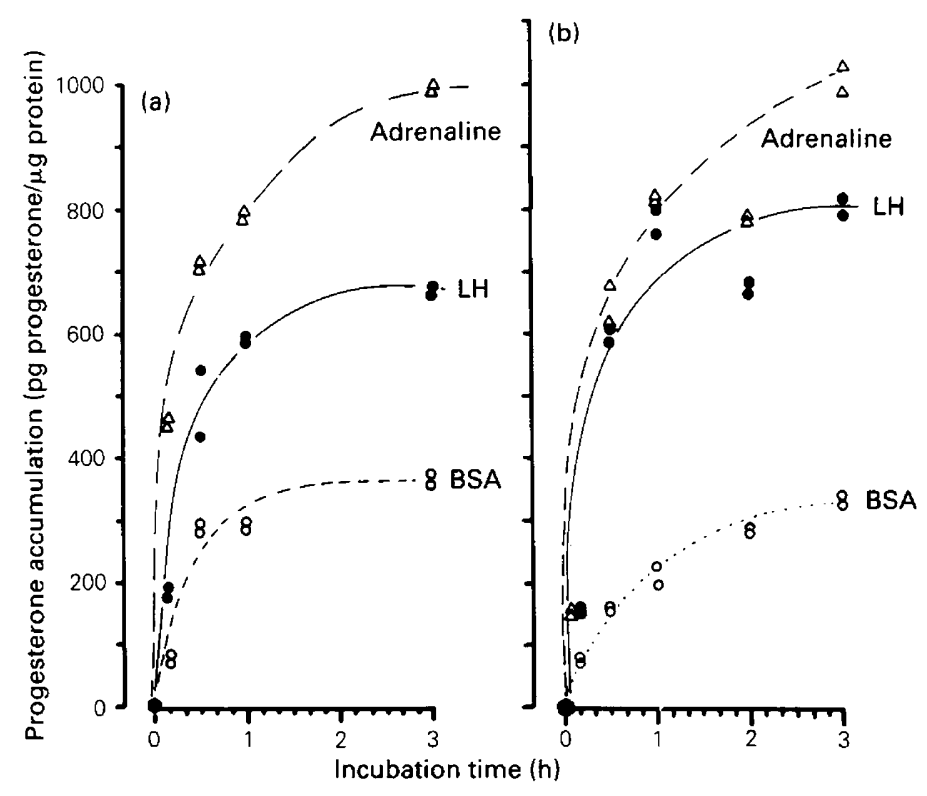

Fig. 1. Effect of $\mathrm{LH}(10 \mu \mathrm{g} / \mathrm{ml})$ and adrenaline $(10 \mu \mathrm{g} / \mathrm{ml})$ on progesterone accumulation by (a) rabbit CL quarters obtained from ovaries of 7-day pseudopregnant rabbits and (b) ovarian slices from PMSG-hCG-primed immature female rats. Control incubations contained BSA $(10 \mu \mathrm{g} / \mathrm{ml})$. Tissue content of progesterone at the start of incubation (time zero) was subtracted from values obtained at each incubation time. Results represent means of triplicate determinations of duplicate incubations of luteal tissue from separate animals and are representative of (a) 3 and (b) 2 separate experiments. $P<0.025$ for BSA $v s$ LH at $10 \mathrm{~min} ; P<0.01$ for BSA $v s$ adrenaline at $10 \mathrm{~min}$ and BSA $v s \mathrm{LH}$ at $3 \mathrm{~h} ; P<0.005$ for BSA $v s \mathrm{LH}$ at $1 \mathrm{~h}$, and for BSA vs adrenaline at 1 and $3 \mathrm{~h}$. 


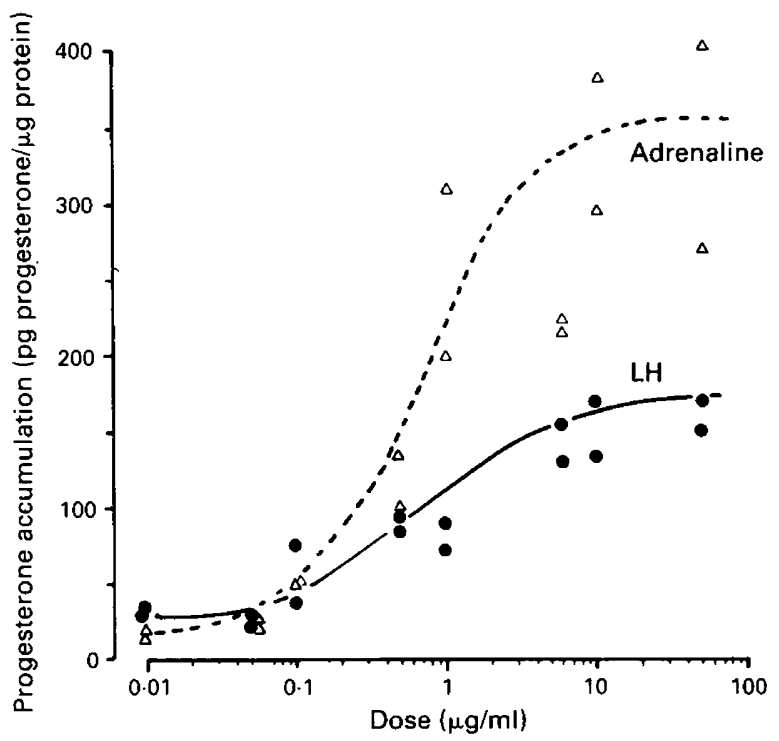

Fig. 2. Effect of LH and adrenaline at different concentrations on the accumulation of progesterone by rabbit CL quarters. Incubations were for $30 \mathrm{~min}$ and progesterone accumulation by $C L$ incubated with BSA was subtracted from values obtained in the presence of hormones. Duplicates of incubations in a single experiment are presented and results are representative of 2 separate experiments.

$(P<0.025)$ and 5.9-fold $(P<0.01)$, respectively. Progesterone accumulation in the presence of BSA, LH or adrenaline plateaued within $3 \mathrm{~h}$. Analysis of dose-response relationships obtained using $30 \mathrm{~min}$ incubations showed that both $\mathrm{LH}$ and adrenaline caused concentration-dependent increases in progesterone accumulation (Fig. 2). Half-maximal activation for LH and adrenaline was achieved with $0.75 \mu \mathrm{g} / \mathrm{ml}$.

In contrast to rabbit CL, the steroidogenic role for $\mathrm{LH}$ in $\mathrm{CL}$ of PMSG-hCG primed immature female rats has been firmly established (Rothchild, 1981). We therefore measured the progesterone synthetic response of ovarian slices from PMSG-hCG-primed immature rats to $\mathrm{LH}$ and adrenaline, and compared these results with those of the rabbit luteal system. A dose-response relationship between $\mathrm{LH}$ and adrenaline and progesterone accumulation equivalent to that shown in Fig. 2 with rabbit CL was observed with the rat system (not shown). Progesterone accumulation by the lutealenriched rat ovarian preparation also exhibited a similar time dependency to that shown by rabbit CL quarters and a similar progesterone synthetic capacity (with our conditions) in the absence of added hormone (BSA) and in the presence of adrenaline (Fig. lb). However, LH was slightly (15\%) more effective (at $3 \mathrm{~h}$ ) in elevating progesterone production in the rat ovarian system compared with that of the rabbit system. Clearly, rabbit luteal tissue responds as well as does the CL-enriched rat ovarian preparation to adrenaline and nearly as well to LH in terms of progesterone production.

These results unequivocally demonstrate that rabbit $\mathrm{CL}$ are capable of an acute steroidogenic response to $\mathrm{LH}$ as well as to adrenaline. The entire steroidogenic response pathway for $\mathrm{LH}$ and adrenaline is therefore present and functional in rabbit CL. Although neither of these hormones appears to be essential to maintain steroidogenesis (Bill \& Keyes, 1983; Gadsby et al., 1985), the presence of this intact cAMP-steroidogenic response pathway suggests that $\mathrm{LH}$ and/or adrenaline may modulate luteal steroidogenesis in rabbits. Further studies are required to clarify whether $\mathrm{LH}$ or adrenaline plays a physiological role in the steroidogenic response of CL in the pituitary-intact rabbit. 
Supported by NIH research grants HD 11356 (M.H.-D.), HD 16192 (A.R.L.), HD 14870 (J.B.M.), and NIH Medical Student Short Term Research Training Program grant AM 107224 (S.D.) and by NIH Research Career Development Award HD 00292 (M.H.D.) and HD 0047 (J.B.M.).

\section{References}

Abramowitz, J., Iyengar, R. \& Birnbaumer, L. (1982) Guanine nucleotide and magnesium ion regulation of the interaction of gonadotropic and $\beta$-adrenergic receptors with their hormones: a comparative study using a single membrane system. Endocrinology 110, 336-346.

Bender, E.M., Miller, J.B., Possley, R.M. \& Keyes, P.L. (1978) Steroidogenic effect of $17 \beta$-estradiol in the rabbit: stimulation of progesterone synthesis in prematurely regressing corpora lutea. Endocrinology 103, 1937-1943.

Bill, C.H., II \& Keyes, P.L. (1983) 173-Estradiol maintains normal function of corpora lutea throughout pseudopregnancy in hypophysectomized rabbits. Biol. Reprod. 28, 608-617.

Cohen, P.P. (1951). Methods for preparation and study of tissues. In Manometric Techniques and Tissue Metabolism, pp. 110-135. Eds W. W. Umbreit, R. H. Burris \& J. S. Stauffer. Burgess Publishing Co., Minneapolis.

Damle, S., LaBarbera, A.R. \& Hunzicker-Dunn, M. (1984) Progesterone production by rabbit corpora lutea in vitro: regulation by $\mathrm{LH}$ and epinephrine. Biol. Reprod. 30 (Suppl. 1), Abstr. 169.

Day, S.L. \& Birnbaumer, L. (1980) Corpus luteum function and adenylyl cyclase stimulability in the rat after an estradiol benzoate induced ovulatory surge of luteinizing hormone: role of prolactin. Endocrinology 106, 382-389.

DeLean, A., Munson, P.S. \& Rodbard, D. (1978) Simultaneous analysis of families of sigmoid curves: application to bioassay, radioligand assay and physiological dose-response curve. Am. J. Physiol. 235, E97-102.

Dorrington, J.H. \& Kilpatrick, R. (1966) Effects of pituitary hormones on progestational hormone production by the rabbit ovary in vivo and in vitro. J. Endocr. 35, 53-63.

Dorrington, J.H. \& Kilpatrick, R. (1967) Effect of adenosine $3^{\prime}, 5^{\prime}$-(cyclic)monophosphate on the synthesis of progestational steroids by rabbit ovarian tissue in vitro. Biochem. J. 104, 725-730.

Drake, R.G. \& Cook, B. (1979) The estrogen receptor of rabbit corpus luteum: binding, dissociation, and stability characteristics. Endocrinology 105, 561-569.

Gadsby, J.E., Keyes, P.L., Schwartz, T.S., Bill, C.H., II \& Lucchesi, B. (1985) Do catecholamines play a physiologic role in regulating corpus luteum function in the pseudopregnant rabbit? Biol. Reprod. 32, 907-915.

Gibori, G., Antczak, E. \& Rothchild, I. (1977) The role of estrogen in the regulation of luteal progesterone secretion in the rat during the period after day 12 of pregnancy. Endocrinology 100, 1483-1495.
Holt, J.A., Keyes, P.L., Brown, J.M. \& Miller, J.B. (1975) Premature regression of corpora lutea in pseudopregnant rabbits following the removal of polydimethylsiloxane capsules containing $17 \beta$ estradiol. Endocrinology 97, 76-82.

Hotchkiss, J., Atkinson, L.E. \& Knobil, E. (1971) Time course of serum estrogen and luteinizing hormone (LH) concentrations during the menstrual cycle of the Rhesus monkey. Endocrinology 89, 177-183.

Hunzicker-Dunn, M. (1981) Selective activation of rabbit ovarian protein kinase isozymes in rabbit ovarian follicles and corpora lutea. J. biol. Chem. 256, 12185-12193.

Hunzicker-Dunn, M. (1982) Epinephrine-sensitive adenylyl cyclase activity in rabbit ovarian tissues. Endocrinology 110, 233-240.

Hunzicker-Dunn, M. \& Birnbaumer, L. (1976) Adenylyl cyclase activities in ovarian tissues. II. Regulation of responsiveness to $\mathrm{LH}, \mathrm{FSH}$ and $\mathrm{PGE}_{1}$ in the rabbit. Endocrinology 99, 185-197.

Hunzicker-Dunn, M. \& Jungmann, R.A. (1978) Effect of an ovulatory dose of human chorionic gonadotropin or luteinizing hormone on the multiplicity of follicular and luteal protein kinases. Endocrinology 103, $431-440$.

Hunzicker-Dunn, M. \& Miller, J.B. (1983) Comparative aspects of corpus luteum function. In Progress in Hormone Biochemistry and Pharmacology, pp. 329 438. Eds M. Briggs \& A. Corbin. Eden Press Inc., Montreal.

Keyes, P.L. \& Nalbandov, A.V. (1967) Maintenance and function of corpora lutea in rabbits depend on estrogen. Endocrinology 80, 938-946.

Lowry, O.H., Rosebrough, N.J., Farr, A.L. \& Randall, R.J. (1951) Protein measurement with the Folin phenol reagent. J. biol. Chem. 193, 265-275.

Miller, J.B. \& Keyes, P.L. (1978) Transition of the rabbit corpus luteum to estrogen dependence during early luteal development. Endocrinology 102, 31-38.

Miller, J.B., LaBarbera, A.R. \& Hunzicker-Dunn, M. (1986) Estradiol suppression of Luteinizing hormone (LH)/human chorionic gonadotropin receptors and LH-sensitive adenylyl cyclase without decreased adenosine $3^{\prime}, 5^{\prime}$-monophosphate content in rabbit corpora lutea. Endocrinology 110, 2016-2023.

Miller, J.B. \& Toft, D.O. (1983) Characterization and physiological variation of estrogen receptors in rabbit corpora lutea throughout pregnancy and pseudopregnancy: the effect of hysterectomy and sustained estradiol treatment. Biol. Reprod. 29, 620-629.

Mills, T.M. \& Osteen, K.G. (1977) 17 $\beta$-Estradiol receptor and progesterone and $20 \alpha$-hydroxy-4-pregnen-3-one content of the developing corpus luteum of rabbit. Endocrinology 101, 1744-1750. 
Rennie, P. (1968) Luteal-hypophyseal interrelationship in the rabbit. Endocrinology 83, 323-328.

Rothchild, I. (1981) The regulation of the mammalian corpus luteum. Recent Prog. Horm. Res. 37, 183-298.

Spies, H.G., Hilliard, J. \& Sawyer, C.H. (1968) Maintenance of corpora lutea and pregnancy in hypophysectomized rabbits. Endocrinology 83, 354-367.
Wilks, J.W., Fuller, G.B. \& Hansel, W. (1970) Role of cholesterol as a progestin precursor in rat, rabbit and bovine luteal tissue. Endocrinology 87, 581-587.

Yuh, K.-C.M. \& Keyes, P.L. (1979) Properties of nuclear and cytoplasmic estrogen receptor in the rabbit corpus luteum: evidence for translocation. Endocrinology 97 , 76-82.

Received 13 June 1986 